\title{
Nordic Winter and Cold: Their Correspondence with Tomas Tranströmer's Poetry
}

\author{
Mohammad Akbar Hosain \\ Lecturer, Department of English \\ Comilla University, Comilla -3506, Bangladesh \\ E-mail: arhosain81@yahoo.com
}

Doi:10.7575/aiac.alls.v.6n.4p.122

Received: 01/04/2015

URL: http://dx.doi.org/10.7575/aiac.alls.v.6n.4p.122

Accepted: 05/06/2015

\begin{abstract}
The Nobel Prize winning poet Tomas Tranströmer was born and bred in Sweden, a remarkably Scandinavian country. Topographically, Scandinavian countries ${ }^{1}$ are locations of extreme cold and snowing. This distinguishing climatic condition has had a dominant influence and impact on almost all Scandinavian art and literature, including Tomas Tranströmer's poetry. The chief aim of this paper is to elaborately explore the impact of Nordic winter and its conditions on the body of Tranströmer's poetry. My paper argues that this impact is of multiple facets, affecting both form and content of his poetry. It also argues that physical as well as psychological landscape is shaped by the penetrating Nordic winter conditions. To achieve the aim, two selections of his poetry (English translation from original Swedish) have been frequently consulted and interpreted, along with a wide range of secondary sources.
\end{abstract}

Keywords: Scandinavian, Nordic, winter and cold, climatic conditions, Swedish, psychological landscape

\section{Introduction}

Nordic countries are especially famous for their extraordinary geographical locations. Sweden, Tranströmer's country is divided into two geographic locales: South Sweden and North Sweden. Because northern Sweden is within the Arctic Circle, it has long, very cold winters. In addition, because of its northern latitude, much of Sweden stays dark for longer periods during the winter and light for more hours in the summer than more southern countries. ${ }^{2}$ If we simply have a glance at the titles of Tomas's poetry, the subject of cold and winter will not surely escape your attention. The biting, severe cold, snow, blizzard and their penetrating trails on human life are vividly present in many of his poems. One of the major aspects in Tomas Tranströmer's poetry is his recurrent use of Nordic winter conditions such as cold, blizzard, snowing, and dark or bleak environment. His winter images on the one hand function as very powerful, rich and evocative symbols; on the other, they render the poet a rare privilege to explore some of his favourite themes- death, loneliness, repression, cohesion, subliminality, salvation and human paradoxes. Used as symbols, the winter conditions illustrate both positive and dark sides of human existence on earth. Surrealistic by nature, his prototypical winter images demonstrate a deep psychology that clearly corresponds to the Jungian tenets.

\section{Winter as symbol of death}

Throughout the tradition of Continental as well as English literature, winter's conditions- snow, blizzard and cold have been seen as the symbol of death. As death is an abstract idea, it is personified in poetry as cold winter and its other attributes. So death has a very vital association with cold winter. In one of Tomas's poems titled as "After Death" (Bly, 28 ) the trails of death are described in the language of cold and snow:

“...It makes the TV pictures snowy

It settles in cold drops on the telephone wires."

Not only that: in the $2^{\text {nd }}$ stanza of the poem, death is directly addressed as 'cold':

"Names swallowed by the cold."

In "Snow is Falling", falling snow is portrayed as 'funerals.' The whiteness of snow brings the image of the whiteness of funeral-goers. Again, another poem "Six Winters" (Tr. Robin Fulton) registers all aspects of a bitter winter: its bleakness, sickness, lethargy and its aftermath a sense of emptiness in the human soul. However, Tranströmer's death poems do not end in 'nothingness' or void. Life and death walk in parallel in his poetry. Even, sometimes the cold death becomes insignificant in the face of warmth of human bond or relationship. The last stanza of "After Death" registers the love and warmth in the heart of human beings making it more vigorous and appealing as it is sharply contrasted with icy death:

"It is still beautiful to feel the heart beat

but often the shadow seems more real than the body.

The samurai looks insignificant

beside his armour of black dragon scales." 


\section{Enjoying nature's miracle and human responsibility}

In many of Tranströmer's poems cold and silence have been simultaneously used. In such poems, a cold and snowy evening is usually marked by silence, quiet and solitariness. Winter and cold have a vital, though not essential, relation to loneliness, solitariness and brooding. At the same time they are associated with pin-drop silence. In many of his poems, Tranströmer broods over in a setting that is cold, silent and almost deserted. Such a poem is "Tracks" (Hass, 35) where a train stands still in the horizon of a plain that is cold with some flickering lights. The poet has created almost a magic scene full of cold and silence to the extent of timelessness. In the first and last stanzas of the poem, the time is 2.am. The poem opens with stillness and ends with stillness. There is no major development and digression. However, this stillness is not intolerable in the least. Rather, with 'bright moonlight' and 'few stars' the poem aspires to be a piece portraying heaven on earth. This poem is one of the best examples where Nordic winter makes miracles showing a fantastic side of cold and winter. This dark, cold and snow have a suitable parallel to one of Robert Frost's poems, "Stopping by Woods on a Snowy Evening" in which a darkest winter evening is transformed into a heaven- the speaker's allure which he can not relish for long because he has greater responsibility in life:

"The woods are lovely, dark and deep.

But I have promises to keep,

And miles to go before I sleep,

And miles to go before I sleep."

However, the speaker in Tranströmer's poem seems to be completely absorbed in the beauty of cold and winter. He does not shun away from the present gift of Nature in the pretext of big responsibility.

\section{Winter and the use of contrast and paradox}

Tranströmer, most of the time, introduces his themes in close contradiction. That's why, love/hate, warmth/cold, winter/summer, centre/margin, physicality/spirituality come hand in hand in his poetry. "Fire Script (Bly. 82)" is a good example for illustrating this aspect of his poetry. Here both physicality and spirituality are set against each other. The 'fire' in the poem means fire in the blood or 'libido' (erotic feelings). The speaking voice very frankly disbosoms this eroticism to his beloved with no indirectness:

"Throughout those dismal months, my soul sat slumped and lifeless

but my body walked to yours."

The weather is dull, 'dismal' and deserted because the winter is very long and soul- consuming. On these days, the poet's male body seeks his lover's one to be warm and ignited. While his physicality is wide awake, his soul is indolent, almost in a state of hibernation: '...my soul sat slumped and lifeless.'

The sharp contrasts that the poet has developed are clear and attractive. 'Life', 'sparked', 'love', ignites', 'flashes', 'body'- these diction lay emphasis on one side of human life: warm physicality. On the other hand, 'dismal', 'slumped', 'lifeless', 'fades', 'dark'- these emphasize the opposite, the antithesis: winter and cold. The vigour and vitality of life becomes sharper, intense and vivid as it is set against the dark and long winter. However, Tomas is a poet of paradoxes and his focus shifts to a spiritual feeling. He ends his poem with an optimism imbued with a transcendental feeling:

"The night heavens gave off moos.

We stole milk from the cosmos and survived."

\section{Cold winter and human relationship}

Tranströmer examines human relationships on the backdrop of freezing winter. Such an example is a prose poem entitled "Below Freezing" (Bly, 72). The very loveless relation between the unidentified 'we' and 'the party' is foreshadowing of what might happen in the latter part of the poem. Lack of love, warmth, cordiality and of friendliness predominates the poem. Here also Tranströmer deals with the contrast between appearance and reality. The party is not merely a gathering of guests laughing, chatting, eating and celebrating. And the 'furnishings' of the party are very 'heavy.' The poet reveals the other side of a seemingly warm and friendly party- 'repressed violence.' So the dark side of human beings lurks behind the friendly party. According to the speaker, the love and sincere affection of the party is merely a mask. When the party reveals itself, the speaker feels horrified to see 'the cold giants' standing on their tracks. However, all these overwhelming cold agents of darkness do not inevitably show that the evil will be the ultimate victor. Along with this cold demon, Tranströmer also points to a patch of sunlight that slips over the houses and the forests. People miss to see the warm sunlight because of the heavy 'furnishings' of the party. But, still sunlight, symbolic of love and warmth, is always there. And the last line of the poem confirms that love (symbolized by 'light') will not be defeated in the long run:

"The light grows as gradually as our hair."

\section{Cold as a symbol of cohesive, natural life}

The use of nature images is a long-standing tradition in Swedish poetry. Poets like August Strindberg (1849-1912) ${ }^{3}$ and Gunnar Ekelöf (1907-1968) ${ }^{4}$ have extensively used images of nature. However, Tranströmer's nature images are unique in their own right because they can be understood on various level of sub-consciousness. ${ }^{5}$

Tomas Tranströmer celebrates life with all its good and bad aspects. What he seriously dislikes is the wearing of a mask: formality and decoration of civilized people. That is why, most often, his poetic personae feels at odd in the company of sophisticated social crowds and dislikes their pleasantries. The poet shows cohesion and symmetry in a 
natural and wild life. The speaking voice in "From March 1979" (Hass, 159) feels weary and fed up with civilized people because they try to communicate with the speaker in 'words', not in 'language.' So the speaker makes his way to 'the snow-covered island'- the wild region and uninhabitable place. 'The snow-covered island' is the poet's symbol of wilderness and symmetry. 'The tracks of deer in the snow' is the poet's equivalent to a communicable language. Thus, 'snow' may be associated, in Tranströmer's imagination, with language, symmetry, naturalness and wildness.

\section{Winter and natural beauty}

In "The Glass House of Tomas Tranströmer", Fred Stern aptly encapsulates the poet's ability to have captured winter and its natural beauty: "If you have ever been to Sweden, especially in winter you can appreciate the crystalline beauty, the starkness of the trees and the brilliance of the stars one can see on any ordinary winter night. All of that is captured in the most unforgettable manner in Tranströmer's poetry."

It is true that Tomas's early poems are much more ornate and decorative than the later ones. His late poems are a mixture of imagism, symbolism, surrealism and most often they have employed less rhetorical devices. ${ }^{6}$ These poems are marked by a special feature of surrealistic type, that is, a certain 'transformation' giving the audience a feeling of awe and surprise. In "Winter's Code" (Hass, 71-72), this 'transformation' magically occurs: the lighted bus in an winter night turns into a ship pacing on a dead canal:

"The bus negotiates the winter night

A flickering ship in the pine forest

On a road as narrow and deep as a dead canal...

If it stopped and switched off its lights

the world would be deleted."

The last stanza (stanza-6), registers the speaker's impression of marvelous beauty of 'snow-haze' moonlight. The amazing moonlight of winter night has totally transformed the 'jellyfish' into a wonder. And the poet ends the poem in a mode of affirmation of life and hope: "... Our smiles/ on the way home. Bewitched avenue." This transformation also occurs more poetically in another of Tranströmer's poems "From the Thaw of 1966" (Hass, 108). Thawing is a change process in which ice and snow turn into water. As deathlike snow in Nordic Sweden turns into water, the bridge is transformed into 'a big iron bird sailing past death.'

\section{Cold winter, catastrophe and transcendental salvation}

Tranströmer's poetry registers several shocks of experience and his intention is to "make the poem a place where these shocks can occur." And most often we see that these shocks of experience occur on the backdrop of winter and cold. On one hand, his poems are significantly marked by a characteristic tone of cold objectivity and dispassionate attitude. On the other, the poems are set in a cold and winter weather. The stylistic frigidity in his poetry is voiced in Tom Sleigh's words:

"The eerie coolness and detachment of his poems is a summons to these shocks that constantly forebode imminent catastrophe." 8

Such a poem of shock is "Loneliness" (Hass, 76). This poem is a telling example of the depiction of a terrifying experience in life, when the poetic personae goes very close to death by a car accident. However, he narrowly escapes, and now what is most important to note is that the mishap occurs in winter, more specifically, on a snowy February evening:

"One evening in February I came near to dying here

the car skidded sideways on the ice;"

And, the poetic personae, when the accident is over and he is unharmed, is gifted with an other-worldly experiencealmost to the point of a transcendental experience- almost like seeing an angel in the cloud to resonate a Blakean term. But unlike William Blake's use of angels Tomas's one is unnamed -simply identified as 'someone' and this 'someone' does not seem to be crooked and deluding. Rather, this agent-of-other-world has appeared to the personae to know of his present condition as he has just returned from an encounter with death. As the previous one- the time of accident, now also the vision of a supernatural becomes visible 'through the whirling snow.' An interesting thing to note: both the shock (here the car accident) and salvation (here the vision of a supernatural being) occur significantly in the same setting of cold, snow and winter. Here, the implication might be- the climatic condition is not to blame- it's not essentially an evil agent causing all harms and havocs to human beings. Still, Tranströmer's poems set in winter and cold give his readers a feel of dimness and uncertainty that, somehow or other his characters are under a spell of foreboding catastrophe. To our mental relief and satisfaction, amid all accidents, calamities and mishaps, his characters are at last gifted with a rare metaphysical experience that sustains and saves them from the onslaught of contemporary complexities of life and living, and most importantly, the meeting of visionary experience saves modern people from sinking into the pitfall of 'nothingness' or 'void." However, Tranströmer reaches such metaphysical perceptions by using very simple pictures from our daily mundane life. Noted critic and reviewer Noah B. Salamon has admitted the poet's inclination to such deep spirituality: "Reading the work of Swedish poet Tomas Tranströmer, one is struck by a sense of its ethereal power, its almost otherworldly presence."

\section{Realistic and indigenous images of cold and winter}

While awarding the Noble Prize to Tranströmer, the Noble Committee especially mentions a common and distinct feature of his poetry: "because through his condensed, translucent images, he gives us fresh access to reality." Tomas's 
long-time friend American poet and critic Robert Bly also stresses the depth of Tranströmer's imagery: "His images emanate from the deep heart's core." 10

Along with this, the poet's distinctness in creating store of imagery is his dependence on the local Swedish culture and colour with its long and penetrating winter tracing effects both on people and animals. He has rendered a big space on his poetic canvass to picture Swedish winter with all its attributes- good or perilous. From this standpoint, Tranströmer has been ranked as a poet true and devoted to his own soil though he has always deserved to be an international poetic voice as well.

\section{Winter and music}

Music is a vital inspiration for Tomas Tranströmer and his poetic creation. Many of his poetry titles, seen at a glance, tell us something what they are about. Such a list can reveal his love and dedication for music- "Grief Gondola No. 2" (Bly, 95-97), “Allegro" (Hass, 60), "Balakirev’s Dream” (Hass, 39), "Lamento" (Hass, 59), “C Major” (Hass, 53), "Schubertiana" (Hass, 143) - all these titles are taken either from classical musical notes or they are titled after classical musicians' names. And surprisingly, the poet has instilled images of cold and winter into these poems.

In his famous music poem, "Grief Gondola No. 2" (Bly, 95-97), Tranströmer pays a tribute to Liszt's piano pieces by the same title. The image of "the green cold of the ocean" transforms later in the poem to "the deep that loves to invade humanity without showing its face." The transformation from 'the cold' to 'the deep' is largely perilous and ominous. The narrating figure has linked cold with transformation in a way that renders to threaten an individual being into a void. The wonder is devilishly changed into a form of evil- the void. Likewise, in "From the Thaw of 1966", we also mark a vital drive of transformation occasioned by the impact of a severe cold and snow. To the narrator's surrealist consciousness, the iron bridge turns into a bird with wings and narrowly evades the fate- death. At the same time, the narrator also demonstrates a feeling of fascination with thawing water ('Old hypnosis'). Both of these images signal a route to emancipation from the void. And Tranströmer's one of the artistic achievements is- he has successfully built a bridge between the void and the human position about it. In Tom Sleigh's words:

“Tranströmer's work constructs spaces that allow us to penetrate to that void, but without denying the contingent nature of the poem's historical moment. By this quiet way of confronting the void in which "the deep sea cold" rises into our being, he makes his poems hospitable to the abyss while still acknowledging vertiginous feel of too much emptiness underneath us."

\section{Psychology, surrealism and cold winter}

Tranströmer's poetry has a close affinity with psychology. Many of his poems can be interpreted as the complex workings of human mind. Critics have noted that the poet himself was a psychologist by vocation and worked for some years in a juvenile rehabilitation centre. And his professional expertise, to some extent, influenced his poetry and lent his creative oeuvre a unique sense of universality. This is clearly acknowledged by the poet's Hungarian translator Ferenc Mervel in the following words:

"Perhaps this is precisely why this is not national, Swedish poetry but universal poetry with a meaning for everyone."

One term that has been occasionally used to mark Tranströmer's imagery is 'deep image. ${ }^{, 11}$ In 1970 s, the critics categorized him as a follower of Jungian tenets ${ }^{12}$ of psychology with their emphasis on 'deep image'. Afterwards, he has been deemed as a proponent of surrealism ${ }^{13}$ and automatic writing as, they argued, his imagery was drawn from 'elemental antimonies': light/dark, stone/water, fire/ice. And with no surprise, we note that many of his poems use the image of winter and cold for the stylistic purpose. An exemplary one may be "Street Crossing" (Bly, 71) which uses contrasting surrealist imagery for the stylistic need.

"Cold winds hit my eyes and two or three suns

dance in the kaleidoscope of tears, as I cross

this street I know so well,

Where the Greenland summer shines from snowpools."

The antimonies have been developed by 'cold wind'/'two or three suns', 'Greenland'/'snowpools'. In the last stanza, the poet says that the street develops human quality of sight or vision and sees the speaking figure.

\section{Thomas Hardy's “The Darkling Thrush" and Tomas Tranströmer's winter poems: a comparison}

Extreme cold, frost and harsh landscape produce perilous effects of disorientation, demotivation, frustration and gloom in human beings. However, poets with their process of creativity and imaginative caliber, overcome these climatic aftermaths. For a convenient comparison and contrast, we have selected Thomas Hardy (1840-1928), a twentieth century English poet and one of the precursors of modernism in English poetry. Both Tranströmer and Hardy are people from two characteristically cold countries. Hardy's brooding nature keeps him very close to Tomas, who has a great many poems on winter. Here we have chosen a Hardy poem "The Darkling Thrush", a remarkable winter poem to compare it with Tomas's winter poems. By comparing the poem with the winter poems by Transtromer, we see that both poets register the above-mentioned damaging effects on human spirit, but the way they attempt to overcome this crisis is what makes a real difference between the two poets. From the very opening of the poem, Hardy notes a gloomy, terrible and desolate landscape wrecked by harsh winter, frost and cold. This feeling of desolation brings his level of life spirit down. His mind sinks into the depth of pessimism and he comes on the brink of 'nothingness.' However, at this dark time of his life, when he is on the verge of collapse, a voice-a singing bird namely a thrush 
restores him to his previous feeling of joy and hope in life. A creature, 'gaunt' and 'small', points to something positive which he has completely overlooked. The thrush points to the fact that, even on the verge of gloom and collapse, there remains some ray of hope making our life worth living and meaningful.

So Hardy retains his hope from Nature, in the famous Wordsworthian secular way. His redemption comes by his own attempts of meditation with no reference to God or a Supernatural Being. On the other hand, Tomas Tranströmer's way is inevitably a spiritual or a religious one, though his spiritual feelings are quite unorthodoxy. His strong and unwavering faith in Christianity and his logical reasoning save him from falling into the pitfalls of 'nihilism.' While Hardy is a secular saint, Tomas is a metaphysical or religious (emphasis given) one. ${ }^{14}$ While in a worst moment of dispirit and frustration, Hardy looks up to nature for salvation. On the other hand, as we have already seen in the poem "Fire Script", Tomas looks upward to overcome the perilous effects of winter on his spirit. Therefore, both of the poets foil the workings of winter's devastation on them in quite different ways.

\section{Conclusion}

In fine, Tomas Tranströmer's use of winter and cold as a subject is quite befitting as we consider his country's geographical location in the cold Scandinavia. He is a successful offshoot of his own soil- a soil globally renowned for its bizarre climatic conditions. Most often he has depicted winter and cold as a necessary part of an atmosphere or a locale, and it renders him a great scope to create astonishing imagery. On the one hand, his use of winter conditions functions as powerful symbols of death, disease, bleakness, and of psychological emptiness in human beings. Cold and freezing winter is also a big canvass on which the poet, with his rare craftsmanship, has nakedly disclosed human evil or fraudulent sociability. At the same time, on the backdrop of this perilous winter he has opened up the artistic gate to salvation. Occasionally, he has used images of Nordic winter and cold for his ingenious stylistic purpose- surrealism. So, now it can be expediently argued that his use of winter and cold has achieved a multi-dimensional aura. This kind of climatic representation in poetry has established him as a globally conscious poet who is deeply rooted in his own soil, Sweden.

\section{Notes:}

1. The term "Scandinavia" covers a large region of Northern Europe. By "Scandinavian countries" we usually mean five countries- Norway, Sweden, Denmark, Finland and Iceland. (Ref. www.geography.about.com)

2. ibid

3. August Strindberg is a Swedish poet, playwright, novelist, essayist and painter. He is called the "father" of modern Swedish literature.

4. Gunnar Ekelöf is a prominent Swedish poet. He is often described as Sweden's first surrealist poet.

5. The importance of 'the subconscious' is vital in Tomas Tranströmer's poetry. In an interview with Tam Lin Neville and Linda Horvath, the poet confesses, "Yes, everything is from inside, from the subconscious. It's the source of everything."(Source: Tomas Tranströmer: The Official Website).

6. Tranströmer's debut collection 17 Dikters is characteristic example of rhetorical poetry, charged with feeling and ambition. But with growing maturity in career, he became more strict and ascetic in form and style. (Ref. www.litera.hu).

7. This is from a seminal article entitled as "Too Much of the Air: Tomas Tranströmer" by Tom Sleigh.

8. ibid

9. In the book review of Tranströmer's The Deleted World, Rob A. Mackenzie notes the reason behind the poet's natural refusal to be deemed as 'nihilistic' poet: "Tranströmer does not fall into this trap, partly due to his precise observation, partly because his poems cannot be reduced to a single mood." (This book review was published in the Umbrella Journal.)

10. The quotation occurs in Robert Bly's 'Introduction' to his own English rendering of Tranströmer's poetry collection The Half-Finished Heaven.

11. The term "deep image" was originally coined by the poets Jerome Rothenberg and Robert Kelly to describe stylized, resonant poetry that operated according to the Symbolist theory and posited a connection between the physical and spiritual realms. Later, the idea was developed by Robert Bly. (Source: www.poetryfoundation.org)

12. Not only critics, even the poet himself talked of his poetry with a reference to the psychological insights pioneered by the Swiss psychologist and philosopher Carl Jung.

13. An Avant-garde movement in art and literature laying emphasis on the uniting of conscious and unconscious realms of experience to express them in the form of dream and fantasy. In such effort, logical and illogical elements are peculiarly juxtaposed to create "an absolute reality, surreality." (Ref. Encyclopedia Britannica).

14. Bly in his introduction, (entitled as "Upward into the Depths") to The Half-finished Heaven emphasizes the poet's "essential religious way."(XXI) 


\section{References}

Bly, Robert. "Upward into the Depths." Introduction. The Half-Finished Heaven: The Best Poems of Tomas Tranströmer. Minneapolis: Graywolf Press, 2001. IX-XXI. Print.

Briney, Amanda.“Geography of Sweden.” About.com.n.d. Web. 20 Apr 2015. 〈http:/geography.about.com〉

Mervel, Ferenc. 'An Interview with the Translator of Tomas Tranströmer.' LITERA.HU. HLO, 13 Oct 2011. Web. 20 Apr 2015. 〈www.hlo.hu/news/two_truths-aproach_each_other_an_interview_with_tomas_transtromer_s_translator〉

Robertson, Robin. "The Double World of Tomas Tranströmer". The New York Review of Books. 14 Oct. 2011. Web. 20 Mar 2015. «www.nybooks.com〉

Salamon, Noah B. "The Transformative Effect of Color in the Poetry of Tomas Tranströmer." World Literature Today. University of Oklahoma,10 June 2014. Web. 23 Apr 2015.

Shmoop Editorial Team.“The Darkling Thrush” Shmoop.com. Shmoop University, Inc., 11 Nov. 2008. Web. 13 Feb. 2015

Sleigh, Tom. “Too Much of the Air: Tomas Tranströmer.” Poets.org. 2005. n.p.,21 Apr. 2015. 〈http://m.poets.org/poetsorg/text/too-much-air-tomas-transtromer〉

Sparknotes Editors. “SparkNote on Frost's Early Poems.” SparkNotes.com. SparkNotesLLC. 2002. Web. 10 Feb. 2015

Stern, Fred. "The Glasshouse of Tomas Tranströmer." Feb 1, 2012. Web. 27 Mar 2015. «www.highbeam.com/doc/1G1282426647>

The Half-Finished Heaven: The Best Poems of Tomas Tranströmer. Trans. Robert Bly. Minneapolis: Graywolf Press, 2001. Print.

“Tomas Tranströmer - Facts”. Nobelprize.org. Nobel Media AB 2014. Web. 27 Mar 2015.

〈http://www.nobelprize.org/nobel_prizes/literature/laureats/2011/transtromer-facts.html〉

Tomas Tranströmer: Selected Poems. Ed. Robert Hass. New Jersey: The Eco Press, 1987. Print.

Tranströmer, Tomas. "Six Winters”. New Collected Poems. Trans. by Robin Fulton, Bloodaxe Books, 1989. Print. 